\title{
Anterograde Headless Cannulated Screw Fixation in the Treatment of Medial Malleolar Fractures: Evaluation of a New Technique and Its Outcomes
}

\author{
Ali Çağrı Tekin ${ }^{a}$ Haluk Çabuk ${ }^{a}$ Süleyman Semih Dedeoğlu ${ }^{a}$ \\ Mehmet Selçuk Saygılıb Müjdat Adaş ${ }^{a}$ Cem Dinçay Büyükkurt ${ }^{a}$ \\ Hakan Gürbüz $^{a}$ Murat Çakar ${ }^{a}$ Zeynep Nilüfer Tekin ${ }^{c}$ \\ ${ }^{a}$ Department of Orthopaedics and Traumatology, Okmeydanı Training and Research Hospital, and betin Sabanci \\ Baltalimani Bone Disease Training and Research Hospital, Istanbul, and ' Department of Radiology, Darıca Farabi \\ Government State Hospital, Darıca, Turkey
}

\section{Key Words}

Medial malleolus · Headless cannulated screw ·

Anterograde fixation

\begin{abstract}
Objective: To evaluate the functional and radiological outcomes of anterograde headless cannulated screw fixation for medial malleolar fractures. Subjects and Methods: This study included 12 patients (8 males, 4 females; age 27-55 years) with medial malleolar type $B$ fractures according to the Herscovici fracture classification who had undergone anterograde headless cannulated screw fixation surgery between 2012 and 2014. Seven had an isolated medial malleolar fracture and 5 a bimalleolar fracture. All of the bimalleolar fractures were classified as 44-B2 based on the Arbeitsgemeinschaft für Osteosynthesefragen/Orthopaedic Trauma Association (AO/OTA) classification. Postoperatively, bone union was evaluated on direct radiographs at the final follow-up examination. The American Orthopaedic Foot and Ankle Society (AOFAS) scoring system was used for clinical evaluation. Results: The mean follow-up period was $17.2 \pm$ 5.3 months (range 12-23). Full union was achieved in all fractures. The mean time to union was $3.4 \pm 1.5$ months (range 2-5). No instability, loss of reduction, non-union or infection
\end{abstract}

\begin{tabular}{ll}
\hline KARGER & $\begin{array}{l}\text { ( } 2016 \text { S. Karger AG, Basel } \\
1011-7571 / 16 / 0255-0429 \$ 39.50 / 0\end{array}$ \\
E-Mail karger@karger.com & $\begin{array}{l}\text { This is an Open Access article licensed under the terms of the } \\
\text { www.karger.com/mpp }\end{array}$ \\
$\begin{array}{l}\text { Creative Commons Attribution-NonCommercial 3.0 Un- } \\
\text { ported license (CC BY-NC) (www.karger.com/OA-license), } \\
\text { applicable to the online version of the article only. Distribu- } \\
\text { tion permitted for non-commercial purposes only. }\end{array}$
\end{tabular}

was observed in any patient. The mean AOFAS score was $95.0 \pm 5.4$ (range 87-99). Based on the AOFAS score, 4 patients showed good results and 8 excellent results. The mean time to return to the previous level of activity was $4.0 \pm 2.5$ months (range 2-5). Conclusion: In this study, anterograde headless cannulated screw fixation yielded good clinical outcome in the surgical treatment of Herscovici type B fractures.

(c) 2016 S. Karger AG, Basel

\section{Introduction}

The aim of operative treatment in ankle fractures is to provide stable internal fixation and allow early motion. Several fixation techniques had been described for the anatomic reduction of fractures, including the Kirschner wire (K-wire) and tension band method, fixation with suture anchors, bioabsorbable screw fixation, a FiberWire loop with a tension band, and bicortical screw fixation [1-3]. In addition to these techniques, fixation with anterograde screws can also be used for medial malleolar fixation [1]. Given that with time the size of the fractured distal fragment in a medial malleolar fracture is insufficient for retrograde fixation [4], the advantage of the an-
Ali Çağrı Tekin, MD

Department of Orthopaedics and Traumatology

Okmeydanı Training and Research Hospital

TR-34384 Istanbul (Turkey)

E-Mail cagrtekin@yahoo.com 
terograde fixation technique over the other techniques is that less dissection of the deltoid ligament is required during both fixation and implant removal [5-7]. Therefore, the aim of this study was to evaluate the functional and radiological outcomes following fixation with anterograde headless cannulated screws in Herscovici type $B$ medial malleolar fractures.

\section{Subjects and Methods}

This study evaluated 12 patients who had undergone surgery from 2012 to 2014 for a medial malleolar type B fracture based on the Herscovici fracture classification system. Approval for the study was granted by the Institutional Ethics Committee of Okmeydanı Training and Research Hospital. The exclusion criteria were a pathological fracture and previous fracture treatment to the ipsilateral lower extremity or multitrauma. All of the bimalleolar fractures were classified as 44-B2 according to the Arbeitsgemeinschaft für Osteosynthesefragen/Orthopaedic Trauma Association (AO/OTA) classification on anteroposterior radiographs. Fibula fractures were all fixated with the plate and screw method. At the final postoperative follow-up examination, bone union was evaluated on direct radiographs. The decisions made in the radiographic evaluation were based on radiological union, disappearance of the fracture line and appearance of a bridging callus. The American Orthopaedic Foot and Ankle Society (AOFAS) scoring system was used for clinical evaluation.

\section{Surgical Technique}

The patients were positioned supine on a radiolucent table, regional anesthesia was administered under tourniquet hemostasis, and the affected extremity was then covered with sterile draping. A longitudinal incision was made along the three posterior edges of the distal fibula in cases of bimalleolar fractures, whereas the incision was made from the lateral surface of the ankle in cases of
Fig. 1. Preoperative X-rays of a 32-year-old man with an isolated medial malleolar fracture.

Fig. 2. Early postoperative X-rays of the patient in figure 1.
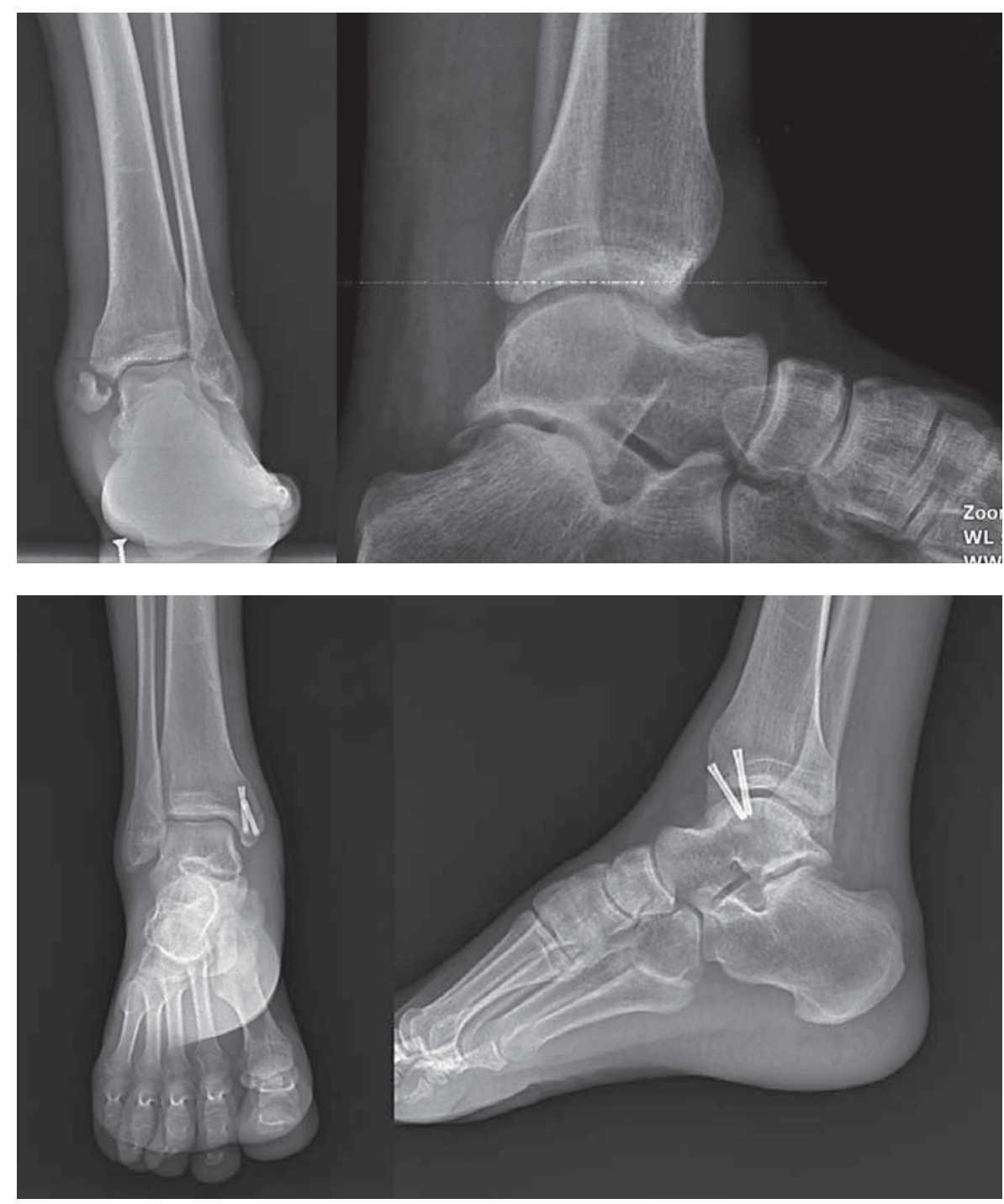

Tekin/Çabuk/Dedeoğlu/Saygıllı/Adaş/ Büyükkurt/Gürbüz/Çakar/Tekin 
fibula fractures. The fracture ends were then exposed through subcutaneous subperiosteal dissection of the fibula. Following fracture reduction, fixation was achieved with an anatomic distal fibula plate. A medial incision of approximately $3-4 \mathrm{~cm}$ was then made, curving distally to the anterior surface at the center of the medial malleolus. While protecting the saphenous vein and nerve, the fracture line was reached. The soft tissue in the fracture line was cleaned, and the distal part of the medial malleolus was measured. Following reduction of the medial malleolus, a 1-mm-thick $\mathrm{K}$-wire was advanced under fluoroscopy guidance from the proximal end of the fracture toward the fracture fragment. The medial malleolus was drilled with a 2-mm drill in the anterograde direction and over the K-wire. Fixation was achieved with a $2.5-\mathrm{mm}$ headless cannulated screw of appropriate length. To prevent rotation of the distal fracture fragment, a second $2.5-\mathrm{mm}$ headless cannulated screw was then implanted using the same technique with an anterograde insertion but at a different angle. The tourniquet was opened, and the blood circulation was checked. The soft tissues were closed appropriately, and a short-leg splint was applied (fig. 1-4).

Postoperative mobilization was allowed with a pair of underarm crutches without weight bearing. The splint was removed in

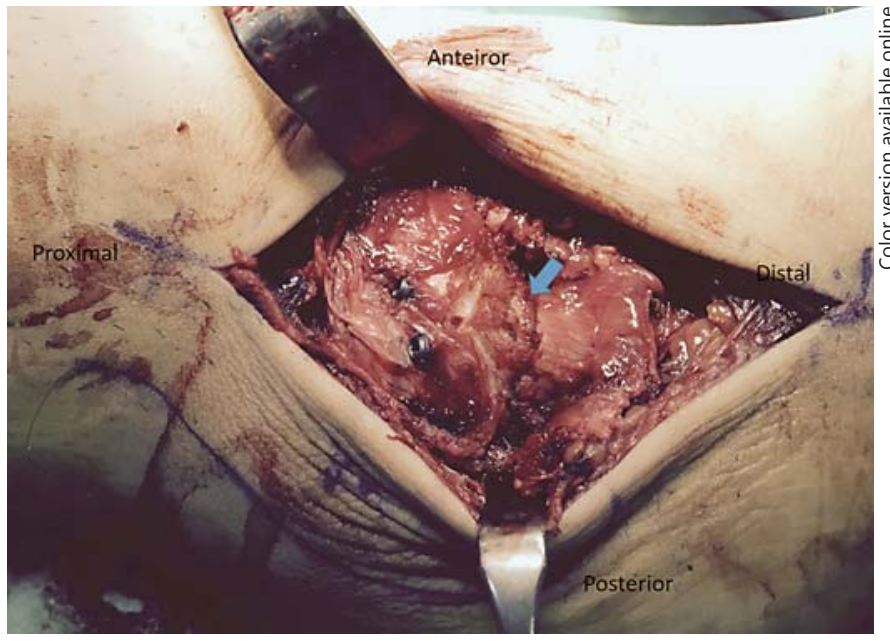

Fig. 3. Intraoperative picture of the patient in figure 1. A small medial malleolar fragment is visible on the right side of the image (arrow), and two 2.5-mm headless cannulated screws are visible on the left.
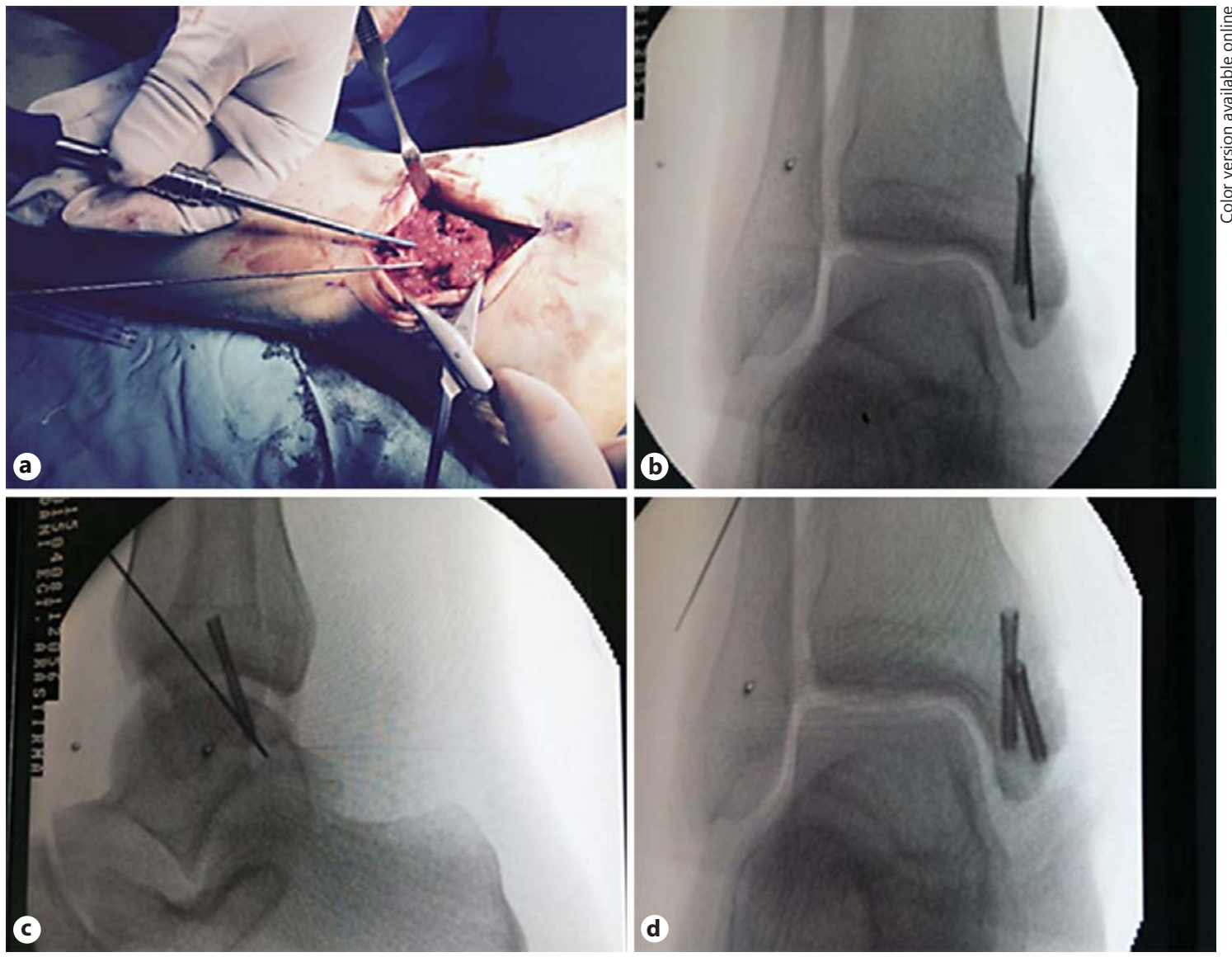

Fig. 4. a Intraoperative K-wire and screw placement. b Anteroposterior fluoroscopic view of the K-wire and screw position. c Lateral fluoroscopic view. d Final position of the screws under fluoroscopic view. 
Fig. 5. X-rays of the patient in figure 1 at 6 months indicating that the fracture had healed.

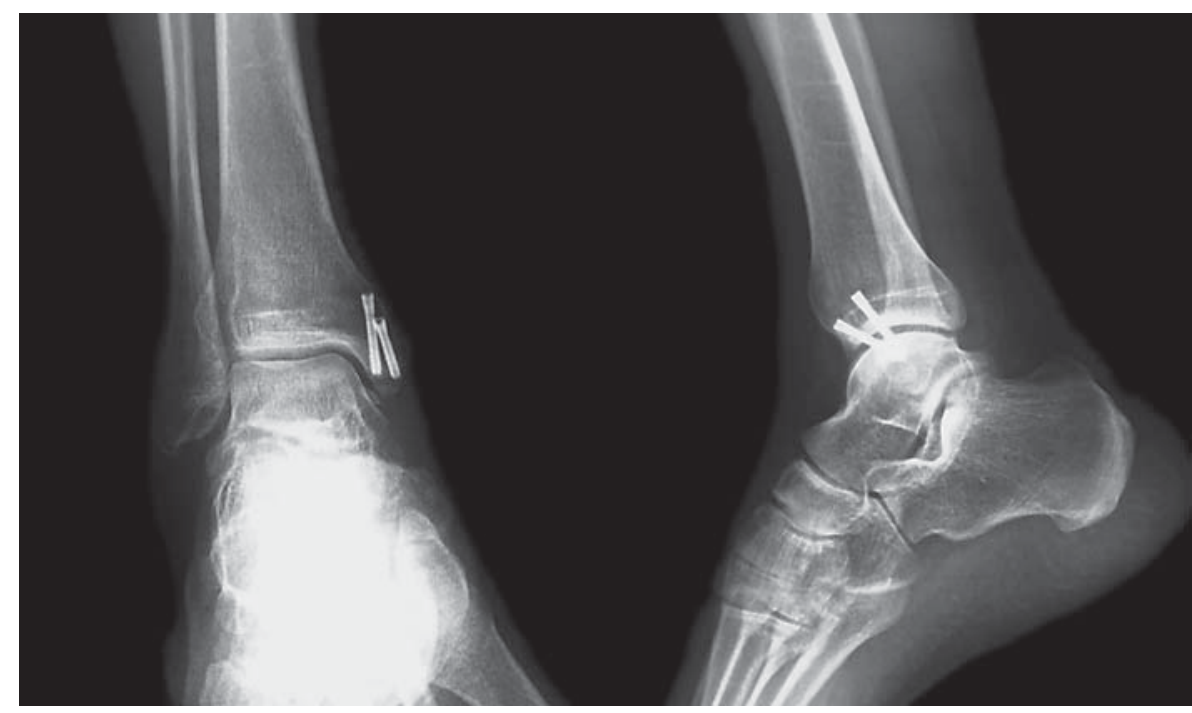

the second week following soft tissue healing, then knee and ankle exercises were started. Partial weight bearing was permitted after radiological healing had been observed (fig. 5) and when the clinical examination was pain-free. After the eighth week, all patients were permitted to use a single crutch, and after the tenth week, unaided ambulation was allowed.

Statistical Analysis

SPSS for Windows version 15.0 (SPSS Inc., Chicago, Ill., USA) was used for statistical analysis. Descriptive statistics including the mean, standard deviation, range, median, minimum, maximum, frequency and ratios were used to describe the study population.

\section{Results}

Of the 12 patients, $8(67 \%)$ were men and $4(33 \%)$ women, with a mean age of $39.3 \pm 9.1$ years (range $27-55$ ). An isolated medial malleolar fracture was present in 7 (58\%) patients, and a bimalleolar fracture was present in $5(42 \%)$ patients. The etiologies of the fractures were a sports injury in $6(50 \%)$ patients and a simple fall in the other 6 (50\%) patients. On the anteroposterior radiographs and in intraoperative measurements, the mean length of the medial malleolus in the distal fragment of the fracture was $9 \mathrm{~mm}$ (range 8-12). The length of the screws used in the medial malleolar screw fixation was between 22 and $26 \mathrm{~mm}$. The mean follow-up period was $17.2 \pm 5.3$ months (range 12-23). Full bone union was achieved in all fractures. The mean time to union was 3.4 \pm 1.5 months (range 2-5). Neither instability, loss of reduction, non-union nor infection was observed in these patients. The mean AOFAS score was $95.0 \pm 5.4$ (range
87-99) (table 1). Based on the AOFAS score, good outcomes were obtained in 4 patients and excellent ones in 8. Arthrosis in the joint line was not observed during the follow-up period. The mean time to return to the previous level of activity was $4.0 \pm 2.5$ months (range $2-5$ ).

\section{Discussion}

In this study, anterograde headless cannulated screw fixation was a good option for the treatment of Herscovici type $B$ fractures because of the good to excellent outcome in all patients; high union rate and no major complications were observed during follow-up. No hardware removal due to irritation from the headless screws was needed. The mean union time and mean time to return to the previous level of activity were similar to those reported in previous studies $[1,8]$, which used headless cannulated screws to repair fractures efficiently and reported limited discomfort. However, in our study, patients did not report any pain or discomfort at the surgical site, probably because anterograde fixation with better soft tissue envelope prevented the risk of hardware prominence.

In the current study, surgical treatment rather than conservative monitoring was used to achieve anatomic reduction because the fractures were intra-articular. Medial malleolar fractures are generally treated surgically, but some reports in the literature describe successful results with conservative treatment for isolated medial malleolar fractures [9]. Herscovici et al. [9] reported that conservative follow-up provided high rates of union and 
Table 1. Patient characteristics and results

\begin{tabular}{lllllllll}
\hline $\begin{array}{l}\text { Patient } \\
\text { No. }\end{array}$ & Gender & $\begin{array}{l}\text { Age, } \\
\text { years }\end{array}$ & Etiology & $\begin{array}{l}\text { AO } \\
\text { classification }\end{array}$ & $\begin{array}{l}\text { Herscovici } \\
\text { classification }\end{array}$ & $\begin{array}{l}\text { Side } \\
\text { AOFAS } \\
\text { result }\end{array}$ & $\begin{array}{l}\text { AOFAS } \\
\text { score }\end{array}$ \\
\hline 1 & F & 55 & fall & $44-\mathrm{B} 2$ & $\mathrm{~B}$ & $\mathrm{R}$ & good & 87 \\
2 & $\mathrm{~F}$ & 48 & fall & $44-\mathrm{A} 2$ & $\mathrm{~B}$ & $\mathrm{~L}$ & excellent & 99 \\
3 & $\mathrm{M}$ & 39 & fall & $44-\mathrm{B} 2$ & $\mathrm{~B}$ & $\mathrm{~L}$ & good & 89 \\
4 & $\mathrm{M}$ & 31 & sports injury & $44-\mathrm{B} 2$ & $\mathrm{~B}$ & $\mathrm{R}$ & excellent & 97 \\
5 & $\mathrm{M}$ & 28 & sports injury & $44-\mathrm{A} 2$ & $\mathrm{~B}$ & $\mathrm{R}$ & excellent & 99 \\
6 & $\mathrm{M}$ & 33 & sports injury & $44-\mathrm{A} 2$ & $\mathrm{~B}$ & $\mathrm{R}$ & excellent & 99 \\
7 & $\mathrm{~F}$ & 45 & fall & $44-\mathrm{B} 2$ & $\mathrm{~B}$ & $\mathrm{~L}$ & good & 87 \\
8 & $\mathrm{M}$ & 32 & fall & $44-\mathrm{A} 2$ & $\mathrm{~B}$ & $\mathrm{~L}$ & excellent & 99 \\
9 & $\mathrm{M}$ & 49 & sports injury & $44-\mathrm{A} 2$ & $\mathrm{~B}$ & $\mathrm{R}$ & excellent & 97 \\
10 & $\mathrm{~F}$ & 41 & fall & $44-\mathrm{B} 2$ & $\mathrm{~B}$ & $\mathrm{R}$ & good & 87 \\
11 & $\mathrm{M}$ & 27 & sports injury & $44-\mathrm{A} 2$ & $\mathrm{~B}$ & $\mathrm{R}$ & excellent & 99 \\
12 & $\mathrm{M}$ & 44 & sports injury & $44-\mathrm{A} 2$ & $\mathrm{~B}$ & $\mathrm{~L}$ & excellent & 97 \\
\hline
\end{tabular}

good functional results in isolated medial malleolar fractures with no ligamentous instability. In that study, the follow-up period was short and the long-term results of conservative treatment were not stated.

In medial malleolar fractures, biomechanical tibiotalar joint contact surface and pressure can vary [10]. Therefore, anatomic reduction is recommended to avoid osteoarthrosis development after the fracture. Whereas it is extremely difficult to obtain anatomic reduction of a fracture with conservative methods, there are several fixation techniques that can be used to achieve this with surgical treatment.

In our study, 12 cases of Herscovici type B medial malleolus fractures were fixated with headless screws in anterograde fashion since the distal part of the fracture was too small for retrograde fixation. The Association for the Study of Internal Fixation (AO-ASIF) recommends that two partially threaded 4-mm lag screws be placed perpendicular to the fracture line in medial malleolar fracture surgery [11]. If the fractures are small avulsions, then the tension band method is recommended unless the screws can be implanted in retrograde fashion. In a biomechanical study, Johnson and Fallat [12] reported that the tension band technique achieved twice the strength of that achieved with the lag screw technique. Fowler et al. [2] stated that a stronger fixation was achieved with bicortical screws than with a tension band. To achieve a stronger fixation with partially threaded lag screws, the threading must be kept short to hold the fracture line [13]. Fixation was achieved in the current study with the anterograde technique. In cases of deltoid ligament damage, especially when there is injury to the superficial tibiocalcaneal ligament, a change occurs in the tibiotalar joint contact area before radiological findings appear [9]. During fracture fixation or implant removal, the deltoid ligament is dissected. Compared to the classical technique, there is less contact with the deltoid ligament in the anterograde technique. Furthermore, there is less postoperative irritation of the deltoid ligament from the screw. This likely reduces the possibility of subsequent injury to the deltoid ligament.

In the current study, 4 of the 12 patients achieved an AOFAS score of good rather than excellent. A review of the AOFAS sub-scores revealed that these 4 patients did not achieve a score of excellent because they were the only patients who experienced intermittent pain. Persistent postoperative pain creates patient dissatisfaction. However, persistent pain or pain associated with implant irritation did not occur in any patient in the current study. Embedding the cannulated screws in the cortical bone is thought to cause less irritation. In $10-15 \%$ of medial malleolar fractures, non-union may be observed with the inclusion of the periosteum and soft tissue in the fracture line. Successful treatment can be achieved with spongious bone graft and rigid screw fixation $[8,14,15]$. No cases of non-union were observed in the current study.

In the present study, screw length was $22-26 \mathrm{~mm}$ for the reverse implant because the screws were implanted in the metaphyseal area. In a study by Ricci et al. [15], the range of screw lengths was $40-45 \mathrm{~mm}$, and the nonunion rate was $20 \%$ with 45 -mm screws implanted in the mid-diaphyseal area. Furthermore, non-union was not observed in medial malleolar fractures treated with headless compression screws. Thus, full bone union was 
achieved in all of the patients of the current study $[8,15]$. The difference in screw length was related to the kind of fixation. In retrograde screw fixation, the starting point was the tip of the medial malleolus to mid-diaphyseal area, whereas in anterograde fixation it was the medial distal metaphyseal region to the tip of the medial malleolus, which had relatively shorter working distance for screw fixation.

Compression in the fracture line has been reported to facilitate union; therefore, compression screws can be selected for fracture fixation. Generally, two screws should be used. However, when fixation is achieved with one screw, a K-wire can be used to prevent rotation $[16,17]$. Unlike in other reports in the literature involving similar procedures, a second headless cannulated screw was preferred in the current study to prevent rotation in the fixation.

In Herscovici type B fractures, it is not always possible to adapt the $24-\mathrm{mm}$ screws to the fracture fragment because the distal fractured segment is small; therefore, these fractures are treated with one screw or the tension band method. If hardware removal through a second operation becomes necessary because sufficient rigid fixation cannot be obtained with one screw or because of irritation when using the tension band method, fixation can be achieved with two $2.5-\mathrm{mm}$ anterograde headless cannulated screws as an alternative method. Despite the small diameter of these screws, clinically sufficient fixation was achieved in the present study. Although we did not encounter the need for hardware removal, it would be difficult to remove the hardware and lose compression strength if the screws had been over-inserted during implantation.

The limitations of this study are the small number of patients, lack of a control group, the retrospective design of the study and a short follow-up period. Future studies could be conducted to compare biomechanical fixation with $2.5-\mathrm{mm}$ diameter anterograde screws and the tension band method for repairing small fractures.

\section{Conclusion}

In this study, headless cannulated screw fixation for Herscovici type B fractures had a good and excellent union rate, no complications and no need to remove screws. Hence, headless cannulated screw fixation should be considered as an alternative method in the treatment of medial malleolar fractures requiring fixation.

\section{References}

1 King CM, Cobb M, Collman DR, et al: Bicortical fixation of medial malleolar fractures: review of 23 cases at risk for complicated bone healing. J Foot Ankle Surg 2012;51:39-44.

- Fowler TT, Pugh KJ, Litsky AS, et al: Medial malleolar fractures: a biomechanical study of fixation techniques. Orthopedics 2011;34: e349-e355.

3 Rangdal S, Singh D, Joshi N, et al: Functional outcome of ankle fracture patients treated with biodegradable implants. Foot Ankle Surg 2012;18:153-156.

4 Parada SA, Krieg JC, Benirschke SK, et al: Bicortical fixation of medial malleolar fractures. Am J Orthop (Belle Mead NJ) 2013;42:90-92.

5 Michelson JD, Hamel AJ, Buczek FL, et al: Kinematic behavior of the ankle following malleolar fracture repair in a high-fidelity cadaver model. J Bone Joint Surg Am 2002;84-A: 2029-2038.

6 Giordano V, Gomes AF, Amaral NP, et al: Preventing surgical complications: a survey on surgeons' perception of intra-articular malleolar screw misplacement in a cadaveric study. Patient Saf Surg 2011;5:24.
Patel T, Owen JR, Byrd WA, et al: Biomechanical performance of a new device for medial malleolar fractures. Foot Ankle Int 2013;34: 426-433.

-8 Barnes H, Cannada LK, Watson JT: A clinical evaluation of alternative fixation techniques for medial malleolus fractures. Injury 2014; 45:1365-1367.

9 Herscovici D Jr, Scaduto JM, Infante A: Conservative treatment of isolated fractures of the medial malleolus. J Bone Joint Surg Br 2007; 89:89-93.

10 Lareau CR, Bariteau JT, Paller DJ, et al: Contribution of the medial malleolus to tibiotalar joint contact characteristics. Foot Ankle Spec 2015;8:23-28.

11 Weber BG, Colton C: Malleolar fractures; in Mueller ME, Allgower M, Schneider R, Willenegger $\mathrm{H}$ (eds): Manual of Internal Fixation: Techniques Recommended by the AO-ASIF Group, ed 3. New York, Springer, 1991, pp 595-612.

12 Johnson BA, Fallat LM: Comparison of tension band wire and cancellous bone screw fixation for medial malleolar fractures. J Foot Ankle Surg 1997;36:284-289.
13 Parker L, Garlick N, McCarthy I, et al: Screw fixation of medial malleolar fractures: a cadaveric biomechanical study challenging the current AO philosophy. Bone Joint J 2013;95B:1662-1666.

14 Carr JB: Malleolar fractures and soft tissue injuries of the ankle; in Browner BD, Jupiter BJ, Levin MA, Trafton GP (eds): Skeletal Trauma, ed 3. Philadelphia, W.B. Saunders, 2003, pp 2307-2374.

15 Ricci WM, Tornetta P, Borrelli J Jr: Lag screw fixation of medial malleolar fractures: a biomechanical, radiographic, and clinical comparison of unicortical partially threaded lag screws and bicortical fully threaded lag screws. J Orthop Trauma 2012;26:602-606.

16 Saini P, Aggrawal A, Meena S, et al: Miniarthrotomy assisted percutaneous screw fixation for displaced medial malleolus fractures - a novel technique. J Clin Orthop Trauma 2014;5:252-256.

17 Perren SM, Frigg R, Hehli M, et al: Lag screw; in Rüedi TP, Murphy WM (eds): AO Principles of Fracture Managment, ed 1. New York, Thieme, 2001, pp 157-167.
Tekin/Çabuk/Dedeoğlu/Saygıllı/Adaş/ Büyükkurt/Gürbüz/Çakar/Tekin 